\title{
On the Protection of the Bottoms of Iron Ships from Concussions and from Fouling
}

\author{
John Grantham Esq., C.E., \&c. \&c.
}

To cite this article: John Grantham Esq., C.E., \&c. \&c. (1862) On the Protection of the Bottoms of Iron Ships from Concussions and from Fouling, Royal United Services Institution. Journal, 6:23, 276-296, DOI: 10.1080/03071846209417185

To link to this article: http://dx.doi.org/10.1080/03071846209417185

曲 Published online: 11 Sep 2009.

Submit your article to this journal $₫$

Џ Article views: 1

Q View related articles $\square$ 


\title{
Gtręnimg aftentetimg.
}

Monday, March 3rd, 1862.

Captain E. G. FISHBOURNE, R.N., C.B. in the Chair.

\section{ON THE PROTECTION OF THE BOTTOMS OF IRON SHIPS FROM CONCUSSIONS AND FROM FOULING.}

\author{
By Jomi Granthay, Esq., C.E., \&c. \&c.
}

Mr. Granthasr.-I think I need no better apology for appearing before you this erening, to explain the subject which I hare to introduce to your notice, than will be afforded by reading a fer lines from the report of the debates in the House of Commons on Friday last. They relate to this special subject, and show, I think, that on the public mind the question we have now to consider is the one which of all others is at present preventing the extension of the use of iron in the building of ships for the Nary. Lord Clarence Paget said: "The honourable Member for Birkenhead was probably better acquainted with the comparative merits of wood and iron than anybody else; but the service of mercantile vessels was a very different thing from the service of men-of-rar. Our ships had to be sent to all parts of the world, and they remained abroad for three or four years. Every practical sailor lnew that a ressel with a foul bottom would neither steam nor sail, and became utterly useless as a man-of-war. We had not jet got orer that difficulty in iron ressels. That it would be eventually orercome he had no doubt; but as long as it existed it would be unwise for the Gorornment snddenly to abandon the building of our smaller ships in rood. Our copper-bottomed ressels were good for two or three jears without going into dock. That would not be the case with iron ships. He beliered, indeed, that with iron ships we would require docks all orer the world; and, upon the whole, he thought we conld not do better than continue the construction of small wooden vessels."

Here the subject turned on the question of fouling.

Mr. W. Duff referred to two iron vessels which were on the South American station when he was there. There were no means of docking them on that station, and at the end of fire jears one of these ressels could hardly move at the rate of two knots an hour. She was one lundred and ten days on her royage home, had to consume her opn bulk- 
heads for fuel, and was giren up for lost; while the other ship was three months on her royage. Until further experiments had been tried, he hoped the noble Lord would not build our vessels entirely of iron. For purely fighting purposes, iron, which would keep out shells, was no doubt desirable, and iron frigates ought to take the place of mooden line-ofbattle ships; but he did not think that the day had arrired for replacing rooden by iron ships on foreign stations.

Again the whole subject seemed to turn on the question of fouling.

Sir J. Elphinstone pointed out that, if iron ressels were sent to distant stations where there were no docks, they mould in conrse of a little time become unserviccable.

A remark was made by $\mathbf{M r}$. Bentinck; but it had reference to another point, not to the question of fouling - viz., the strength of the bottom of iron ships.

Mr. Bentinck said: "As to iron ships being stronger than rooden ships, that was true in some cases; but in others it was not so. If an iron ressel went ashore upon a sandbank, she would hang on there a long time; but if she rent upon a stony or rocks shore, she would go to pieces like brown paper."

That $I$ think is an extreme riew of the case; but it eridently had reference to the facility with which iron ships are pierced by hard bodies.

Mr. Laird, speaking on the subject of docks, said " he was rather surprised, looking at the increased size of the ships now building, and the very inadequate number of graring docks, that a larger sum was not taken to remedy this state of things. There ras scarcely any graring dock that could take these ressels in. At Portsmouth there mas only one, and he wished to know what steps were to be taken to provide tho requisite accommodation."

Mr. Corrie speaks on the same subject, especially with reference to the nrcessity of frequently docking iron ships.

I had the honour last year of bringing under the notice of this Institution the subject contained in tho present paper. It was then however only mentioned incidentally in the course of the discussions mhich followed Captain Halsted's paper on Iron Ships for the Nary. It is felt that an erening devoted to this question will not be time lost, and that the paper now to be read, and the discussions that may follow, may tend to throw some light upon and clear up some of the difficulties in the way of the removal of the only remaining objection to the employment of iron ships for the Navy. All subjects of this kind must be relative; no one is sanguine enough to suppose that a ship can be rendered inrulnerable to rocks, or kept under all circumstances free from the adhesion of weeds and shells; we can only attain to approximate safety, and all modern improrements are only so many steps in attaining to greater security, higher specds, and a better adaptation generally for the requirements of ships. These relatire qualities can only bo measured by what has gonn before; therefore the best we can claim is to have done something better.

Now beyond all question iron possesses qualities that render it better adapted than wood for shipbuilding, and yet we, its most sanguine advocates, have never denied that certain defects have to be remored before superiority can be claimed for it in all its features. 


\section{ON THE PROTLCTION OF THE BOTTOMS OF IRON SHIPS}

In my orm rork on Iron Ships, mitten sbout trenty Jears ago, and of which a second edition appeared in 1858 , the following remarks occur:-

"There is one source of risk to which iron ships are more liable than timber-bnilt ships; I allude to the effect of a blor from a hard and pointed substance, such as the fiuke of an anchor or a sharp rock. These liave been found to penetrate the iron plates more freely than through the planks of a timber ship, supported as they are by the ribs, which form an almost solid bed under them." Again, "The fact that iron ressels become coated in tropical climates with shells and meeds, has operated considerably against them. . . . That the objection exists cannot be denied, and it constitutes at present the most annoying circumstauce connected with iron ships."

These quotations show that these drawbacks to iron ships are not now, as some suppose, discorered for the first time: we lare long known them, and hare never concealed them; but, in spite of them, iron ships are fast taking the place of rooden ones.

In the first case, to meet the disadrantage of haring the plates pierced, we say, multiply the bulkheads as much as possible, and make them strong enough; and we also recommend those who narigate iron ships not to go tupon rocks !

In the second, we say, apply such compositions as experience shors will keep longest clean; and when four ship goes to a tropical climate, get home as quick as you can, and put her in dock and clean her; but te are obliged to admit that if iron ships aro to become unirersal they will get on rocks, and they must also be detained in climates where they will become foul.

It mall be readils supposed that those practical men who have long been engaged in iron-ship building have given these questions their anxious attention; we hare long been aware that copper sheathing is the only permanent remedy knomn for resisting the tendency of a ship to foul; and in proposing a system by which this may be safely applied to an iron ship, a practical method of enabling them to resist concussions from hard substances lins also suggested itself.

Many attempts hare been made to attach copper direct to the plates by some principle of adbesion, and one of these will, I beliere, be cxhibited to yon to-night. I tried many of these some years ago, but abandoned them nll; I then suggested the plan now before you. One man actually sheathed an iron ship formerly belonging to our Government with planks, and secured them by means of an immense number of bolts put through the plates, orer this ho placed copper, and the ressel had made tro royages into the Pacific when I last heard of her; but as the system of bolting was in itself bad, I cannot suppose that it could hare any farourable result.

Another man, howerer-Mr. Jordan of Liverpool-made a much more successful attempt; and as it bears on our present question in many important respects, I shall again refer to it; but before doing so I rill repeat some well-knomn reasons why the varions compositions now in use do not meet the requirements of the case, nor act as copper does in preserring the ship from fouling.

It is knom that the effect produced on shell-fish and reeds by the 
copper is not purely a chemical question, but must rather be called mechanical. The oxidation of the copper, by constantly reducing its outer surface, prevents substances from adhering permanently to it. This has been show $n$ when attempts were made to arrest the oxidation by a galranic action being given to it; but the ship then became foul; shell-fish and reeds were not thrown off, and they had time to grow, as on iron ships.

I aroid specifying or giring more than in general opinion on the rarious compositions that are sold as remedies for this great eril; the fullest opportunities have now for some jears been giren them, and let the experience thus gained speak for itself. Upwards of twenty years ago, when the evil of fonling began to be sencibly felt, iron-ship builders used a composition that was considered efficacions, but which it was soon found was rery partially successful. Some that I have secn since, and which hare been claimed as new, were of a similar character. I may say generally that they cannot be substitutes for copper, because their action, if any, differs so much from it; none of them present a surface that is continually changing by the process of oxidation. Some of them present a smooth surface, and this naturally will keep clean longer than a rougher surface; but none of them, so far as I lnow, hare been able to resist for any length of time the slow encroachinents of that animal and regetable life that arrests the carcer of the most porerful ships.

Like many others, I have contended that some simple thing would be found to meet the case, but time has produced nothing. For many years the subject has been under the anxious consideration of our best naturalists, chemists, and practical men, and, as far as I can judge, some of our first attempts at a remedy were as good, or nearly so, as any that have succeeded them. The cry still is, let us wait and sometling will be found; but I beliere that nothing at present but copper grves any prospect of success, and the plan here presented to you admits of the ship being coppered while it is otherwise a protection to her against concussions.

Now it is remarkible that men who have long resisted any particular improrements or discoreries, no sooner become converts, than they fall into the opposite extreme and show an undue confidence in the nerr system. This has been remarlably illustrated in the rarious stages in the progress of iron-ship building, and this eril of fouling which the long consistent adrocates of this material have felt to be so serious, is now said to be of minor importance. Why, Sir, the whole question of the fitness of the general introduction of iron ships into the Nary tums on this very question. Witness, amongst other things, the frequent remarks to this effect in the debates in the Honse of Commons. Not that remedies for this eril are not required for the merchant service, but they appear to be essential in the Nary. For a moment consider the case of the " Warrior," in herself a great success; in such a ship a high relocity is considered an essential qualification, and, whaterer adrantages iron may possess, they must all be given up if the adoption of it is to result in a diminution of speed. $\Lambda$ bout $£ 80,000$ has been spent on lier machinery; a large amount of space has been sacrificed to it, and the coals, of which about 150 tons per diem are required to drive her at full speed; and what will be the result? Send her into the Miediterranean, the gulf of Mexico, or to India, and, if left there, in a short time her speed will be seriously reduced 
and in six months her fourteen-knot speed will probably be ten, and in twelve months much less-probably seren would be her best speed. It is truc when she gets into this state she may be cleaned, if jou can get her into a graving dock, perhaps 1,000 miles from her station, or she may, if she can find it, be forced up into a fresh-water river, and there, after lying some time, be partially cleaned by the death of the weeds and animalcula, whos: natural clement is salt water, and which camnot live in fresh. And then what follows? the ship is no sooner at sea again than the same process commences, only to be remored by resorting to a repetition of the same means. I suppose, howerer, that no graring docks out of Europe rould receive our hearily-plated ships.

Now, that I hare not overstated the case, I refer to the specimen of a moderate-sized barnacle, attached to the model of this arrangement, now in this MIuseum. This was one of many thousands taken from an iron ship, and is the growth probably of six or twelve months. When attached to the ship in its live state, a fish about as long as one's finger projects from every shell, causing a still more formidable obstruction.

But the case may be illustrated by well-known facts that occur in this climate, where slells seldom attach themselves, but which is due to reeds only, with a certain amount of roughness that rises in salt water upon ordinary paint. Every iron ressel for the first month after leaving the graving dock and having the plates cleaned, gocs better than she does subsequently. This has been accurately tested by tho new ressels belonging to the City of Dublin Steam Packet Company, which carry the mails from Holyhead to Kingstown. In the summer time, in about trro months after leaving the graving dock, their speed uniformly falls off so as to increase the length of the passage ten to fiftecn minutes, or equal to about half a mile to one mile an hour. After the first tro or three months the retarding process in this country goes on slowly, but where shells attach themsclres the contrary is the case. From these facts I am led to the conriction, which I have frequently heard expressed by others, viz., that in some cases, eren in this country, it might be worth while to use copper for iron ships, should my plan prove successful. As the royages of iron ships in the merchant service are extended, the evil is being increasingly felt. Large sums hare been expended in Liverpool on the most splendid graring docks in the world, but, owing to the necessity of constantly docking the numerous large iron steamers now owned in that port, a much greater expenditure has become necessary to licep pace with the demand.

Having, I trust, shown some grounds for supposing that copper sheathing would be desirable if it could be applied, I now ask your attention to the drawings, and you will see that while the first object sought was a remedy for fouling, the same sJstem supplies a very effectual protection against concussions, an adrantage that must to come extent satisfy the requirements eren of the strongest opponents to iron ships for the Nary. It will be seen that I commence by attaching frames to the outside of the vessel to run up to the light water-line, or to the armour-plat $I_{\text {s }}$ in large plate-clad ships. These frames are rolled like common angle ir on, except that the outside edge is made of a wedge form, or flanged, as shown in the drawings; they are rireted to the ship in the usual manner. Between these is driren a timber planking, which becomes firmly wedged; 
GRANTHAMS SHEATIING FOR IRON SHIYS.
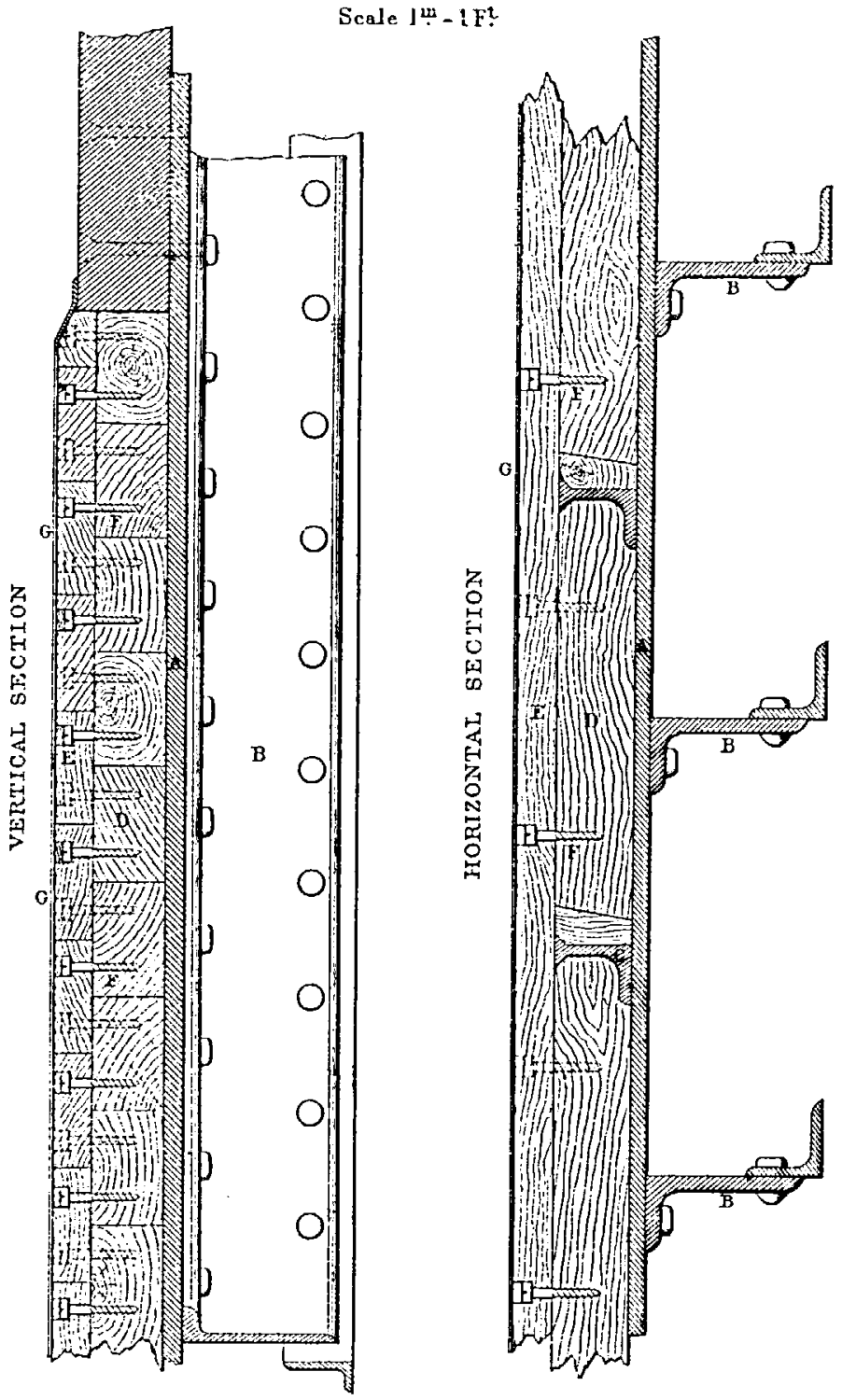

A. Section of Sille "lates

F. Ouler Planks

13 . Inside Frames.

F. Brass Scrav Bolts

(; Oulside Frames

1) . Imnst Planks

(G Copper Sheathing 
and being set in with suitable compositions, and then caulked, forms a solid bed. This would be made from refuse timber cut from the rood used in the other parts of the ship. The whole being then dubbed eren with the ribs, and again coated, another sheathing is attached by brass screms. I have made the inner one for large ships four inches thick, and the onter one tro inches. The copper sheathing is then attached in the usual way.

Thus a firm substantial bed is prepared for the copper, all metallic contact is aroided, and great additional protection is given to the bottom of the ressel. I will endearour nor to anticipate and reply to the objections that may be used against this system.

1st. That it will be expensive;

2nd. That it will add to the weight of the ressel;

3rd. That it will injure the iron plates;

4th. That the timber work will become loose when the vessel strains.

There may be others which may bo snggested during the discussions that I hope will follow the reading of this paper, and therefore I will deal with those I have named as briefly as possible. In all these discussions I take the "Warrior" as the vessel to which allusions and comparisons will be made, being most deservedly greatly in adrance of all other ships in public opinion.

1st. $\Lambda$ s regards the expense. I estimate the timber, labour, screws, and coating at less than $£ 4,000$, if put on when the ship is building, on a ship valued at $£ 350,000$. The copper is not included. I claim against this, in making a ship of equal safety, a saving of 200 tons of iron, which, at $£ 20$ per ton, equals $£ 4,000$. But by far the largest set-off is to be found in the saving of steam-power, and for foreign service, I set this down in the "Wamior" at 500 horses, upon the average of a three years" cruise in rarm climates, or 200 horses in the home serrice; or, what is more important still, that the ressel shall, if kept clean, at all times maintain her proper speed.

2nd. If the comparison is to be fairly carried out, the increase of weight will be very little. I claim a saving of 200 tons of iron, and the timber will meigh 280 tons, a difference of 80 tons in a ressel displacing 8,000 to 9,000 tons.

3rd. I deny that it will injure the plates; on the contrary, I assert that it will be a great protection to them, for being once well painted, the sheathing will effectually protect the paint, and while this remains unbroken, there is no fear of corrosion. There being no bolts to work loose, and no metallic contact, there is abundant evidence to show that the plates of irou ships, under such circumstances, will be entirely freo from injury.

In some respects the iron-clad ships, as hitherto constructed, are much more unfarourably placed, a large portion of the woodwork which is used as a backing for the armour plates is below the water-line, having a 1,000 tous more or less of weight outside of it, suspended by bolts about two feet long running through the timber; and iron bolts that will loosen, and in time admit water, a defect that cannot take place with the sheathing now proposed-First, because there are no bolts; and secondly, instead of having a power tending to loosen 2 t, there vill be a pressure YOL. YI. 
of water equal to the weight of the slip, tending to make it cling to her sides and bottown, a power that no ordinary means could orercome.

I hare heard it asserted that injury to the plates may go on unobserred beneath the roodwork. In the first place, the probability of such injury is rery remote; at the worst the water can only penetrate to the plates and there remain quiet, and even there the coating will arrest its progress; but supposing further the plates to have no protection, what is to be apprehended? the water is at once deprived of its oxygen, an infinitely small amount of corrosion takes place, and then all further mischief ceases. If there rere a constant stream or jet of water, damage might occur: but this would be impossible; it could at the worst only penetrate, and there remain at rest. Such alanns as these are only a repetition of what was experienced when iron slips first were used on salt rater. It was then confidently asserted that they could not witlistand the corrosion, but must soon perish. We now find that iron ships, mell protected, are rery durable.

But I lave alluded to other evidence, viz. the ressels built by Mr. Jordan, as proring that iron in contact with wood sheathing and copper, though rery unfarourably placed, lias stood well for ten years.

Mr. Jordan's ressels were built with angle-iron frames and several plate ribbon-pices, having planks sectred by iron bolts outside all. These ships were coppered, and rere in the Enst Indies since they were butil in 1851 ; one of 400 tous was lost about tro years ago, and one of 780 tons is still at rork. As regards the plates and ribs, both ressels are said to hare been in excellent condition, though exposed to rery severe trials. The iron bolts which approach nearly to the copper have suffered as wight be expected, and as rould hare been the case to a certain extent had there been no copper. The owner, a man of great experience, declares in a letter lately irritten to me that he rould nerer build on sny other sjstem. I will quote a few of his remarks. Of the ressel that was lost, lie said " that the bolts were to a considerable extent affected, although no other part of the iron frameriork was so. At the same time, it must be remembered that these bolts had been fully eight years in use, and mere still strong enough to do their work. There was the utmost harnony between the wood and the iron; no straining was ever apparent, and consequently not the slightest devintion in the shecr or form of the ressel. With all the strength of iron, they had all the advantages of wooden ships-no fouling, for they were nlways coppered."

4th. The last objection which I hare anticipated is, that the timber will work loose. Those who hare raised this objection can surely not have ieflected on what they were saying. Observe the drawing, and it will be seen that the means for securing the planks are much better than the ordinary means used for attaching them to a rooden ship; in this sheathing the planks are wedged most powerfully at very short interrals betreen frames, which themselres are riveted to plates that are perfectly unyiclding in the direction in which the seans conld open. Should any fielding take place, it can only arise from the plates cracking or the seams opening, and we know this to be last extremity of an iron ship. In fact, in a sound ressel such motion is impossible. But there is another action found in all ships-riz., the bending of the whole fabric then 
working in a heary sea. I lave endeavoured to reduce the amount of this to figures, for in no other way could I estimate it, the norement on cach joint being inappreciably small.

I do not know whether the lateral motion of the "Warior" has been ascertained; but $I$ have assumed it to be four inches in her entire length, in shich case I make the arerage opening at the onter edge of each scam in the lengthrrass of the ship to be about the 17,000th part of an inch, or the 70th part of the thickness of an ordinary slicet of mriting-paper, and the inner edge of the seam to be absolutely nothing but what may bo allowed for in the positive dircet stretching of the plate betreen each frame at every motion of the ship.

No one for a moment will donbt that the elasticity of the timber will much more than compensate for these small morements; and it may here be well to consider how this principlo acts in erery timber slip, and is essential to its safety-its rery existence depends on the porrer in the timber and oaknm of its seams to expand and contract; for, suppose they had not that propert5, but in that respect rere like lead, which can bo compressed, bat will not expand again, haring little or no clasticity, it is probable such a ship would founder in the first gale. May I not clnim in this argument some benefit from a principle which is the sole dependence of erery ship made of timber?

In the matter of repairs, it may be asked, Can the rood-mork be easily replaced should part of it be damaged? To this I may reply that $I$ beliere it will be perfectly casy; the inner plank may be set fast by a double redge at any part of the ressel rithout disturbing the rest.

I hare now rery briefly to ask jour attention to this system in its action, as a buffer in case of collision with hard bodies. That it will so act is self-evident: externally it will endure whaterer ordinary jianks will, internally it will tend to spread the effect of the blow orer a larger space; it will likewise interpose an elastic substance, which, in itself, will materially lessen the effect of the direct contact with a rock or other hard body. It may be a question worth considering whether the outer plank should not be stronger than $I$ have shom it in the flat of the floor, and in those parts where coutact with rocks is most to be apprehended.

In closing this paper I very reluctantly turn to some personal considerations. I will not renture to predict what judgment will here be passed on my remarks; I can only state what I know, riz., that this plan was described to gentlemen connceted with the Admiralty about ten years ngo. It was shown to $\mathrm{Sir}$ Baldwin Walker about three years ago, it has since been strongly recommended for adoption by the Plate Committee, and has been noticed by sereral scientific joumals, in all cascs farourably. It has also reccired the written and rerbal approral of men whose opinions rould always carry weight; but to this time no attempt has been made to test its qualities. The trial of it or any comesponding plan cannot be made in a day; it will take jears before it can be fairly testel. Norr, supposing a trial had been made in the year 1852 , when I first made it known, and it had met with approral, I beliere not a single mocdçn gunboat would hare been built for the Russian war, but that all would have been of iron; or, if Sir Balduin Walker had recommended a trial threc years ago, and it had succeeded, we should in all our new iron ships have 


\section{ON THE PROTECTION OF THE BOTTOMS OF IRON SHIPS}

lad a system on which dependence conld be placed for the removal of the only drawbacks to the entire adoption of iron ships for the Nary.

The unfair question is put to me, Where are your examples, on what ships has it been tried? I ask, Who is likely to try it if the Government will not, for who has so large a stake in it? Can an indiridual try it? It has already cost me nearly 500l. in the mere introduction of it to notice. Can I be expected to do more? Its adrantages cannot be fully appreciated in small vessels, though it is applicable to all; its principal recommendation is for large ones, and such ressels inrolve large sums; and when I request that a trial may be made, I ask for no great sacrifice or risk in making it. It could not destroy the usefulness of the ship, even though it might not hare all the adrantages which I propose. Is it, therefore, too much to hope that such a ship should be designed? and I have no hesitation in predicting that, while having all the adrantages of a timber-built ship in its power to resist concussion on rocks and fouling, so that it may be sent on a foreign station for three or four years without being docked, it will be superior in strength, of greater internal capacity, more free from leakage and other inconreniences, will sail faster because of less weight, and will cost less money both in building and keeping in repair. Such a trial, if successful, will remore the greatest objection now affecting the progress of iron ships, to the great benefit of the Gorernment and the merchant service of this country.

R. Mlaleet, Esq., C.E., F.R.S.-The honour of haring been asked to make a few remarks upon the paper which has just been read has, no doubt, been done me from the fact that several years since I myself made some researches on the subject of the corrosion and the fouling of iron, which have been published in four different Reports by the British Association for the Adrancement of Science in the Jears 1839-41-43 and 49; ard although not an iron-ship builder, jet haring, as a ciril and mechanical engineer, and for several years the active partner of an engineering firm, been familiar all my life with the practical applications of iron, and especially with its uses in the form of structural works of plate and angle iron, \&c., \&c., often as nuch exposed to corrosion as iron ships, eo I am cnabled to form a practical judgment on the subject brought to-night before the Royal United Service Institution. The importance of the subject itself, as Mr. Grantham has stated, I think it would be difficult to orerrate; for, highly important as the corrosion and fouling of iron ships has been at all times to the mercantile marine in a money sense, it becomes of far more rital importance now that iron ships are certain to be applied for war purposes; for if it be a fact that a war ship sent to sea, after some six or eight weeks loses a mile an hour of her speed from alteration of the surface of her immense hull, or, as we may call it, from fouling, -if a ressel so circnmstanced be caught by a clean ship of the enemy that has got the mile an hour still, the former is taken at a disadrantage which nothing can make up for, and so the mere state of her surface determines whether she can keep the seas or not. Hence this question of fouling has become a national one.

There are three aspects or three directions in which perhaps it will be well to make a few remarks in opening the discussion on this paper. The sulject has its bearings of a directly chemical or physical character as respects corrosion and as respects fouling, and it has a practical character 
as regards construction, that is to say, in what way, and to what cxtent principles determined by the chemist and physicist, can be practically carried out by the shipbuilder.

As respects the first, it will be perhaps adrantageous if I very briefly lead back the attention of those who may not perhaps at all hare considered the effects of corrosion and fouling, to a fer of the fundamental facts of the subject, ascertained by mysclf principalls, I may say; indeed, I hope I shall not be guilty of any immodesty were I to say altogether; for, so far as my knowledge goes, those four reports of mine up to this present embrace almost the whole of the scientific literature that exists on the subject of the corrosion and fouling of iron ships, and of iron generally.

Iron is only acted upon in the way of corrosion by water, whether it be fre sh or salt, that also contains air in combination. All the water we find in nature contains a certain quantity of dissolred air, and the air it does contain-combined in the same way that we find the carbonic acid is in a bottle of soda-water-possesses a larger proportion of oxygen than exists in the air we breathe, i.e., in the atmosphere. If a piece of iron be placed in water from which this combined air has been exhausted, whether tho water be salt or fresh, at the ordinary temperature, no corrosion takes place; but if it be exposed to the action of water with this combined air, or air and water togetler in any other way, or to each alternately, then corrosion does talie place; and up to the present hour science has failed to derise any means by which that corrosire action slall be completely arrested. . All the various derices of coating with other metals, such as with zinc, usually called galranising, are found to be perfectly nugntory, under the abore circumstances of exposure and constant moisture. Even in perfectly pure fresh water, galvanising-coating the surface with zincis a palliatire of corrosion and no more. In sea rater it is entirely useless, and as applied to iron ships it would be absolutely hurtful, because, independent of any ill effects unon the toughness of the iron, one of the effects of any partial remoral of the thin surface conting of zine is that a thin coating of carbonate of lime is rapidly deposited npon that which remains, and upon that excessirely thin bed of lime fouling takes place immediately_-plants and animals readily attach themselres to it.

I do not despair, howerer, of science hereafter being cnabled to make an iron ship as invulnerable to corrosion as if it were a piece of platina. I may just illustrate the conceivability of this by repeating a very simple experiment, first due to Professor Schoenbein of Basle, the discoverer of what is called the passivity of iron. Here are tro pieces of common shect iron. and a piece of platina. Here is an acid which is capable of rapidly corroding and eren dissolring a piece of iron in its ordinary condition when plunged in it directly: this acid does not act on platina at all. If, howerer, in place of putting the piece of iron into the acid directly, in which case it would instantly begin to be acted upon, I touch it first with the piece of platina, and immerse the tro together, and then withdraw the platina, the iron remains in the acid in a perfectly passive condition; the acid, which is capable of dissolring the whole piece of iron in a rery fer minutes, does not now act upon it at all, it remains as passire and as incorrodible as does the platina itself. Further, if I now take another piece of iron which has not been touched by the platina, and touch it with the piece which has 
been alrendy touched and inmersed, it will be found that the latter piece of iron is now in the condition to lring another piece of iron into the same condition with itself, and so in its turn this second piece would not be acted upon; and so we might go on for ever. But if I put a piece of iron which has not been touched by the platina, or by another piece of iron so tonched, into the acid, it mill be acted upon directly; and if I touch it now with the platina while in the acil or withdramn from it, this Fill not now prevent its being corroded, nor arrest the corrosion that has commenced. This little experiment suffices to show that iron, one of the most singular bodies amongst all the elements with which we are acquainted, martellously endorsed with properties fitting it for the uses of man, has yet unseen and undiscovered properties, such as those Bacon talked of long ngo, when lie said nature still containeth secrets more martellous and potent than the wit of man hath yet conceived, much less discovered. It indicates the possibility that iron still contnins scerets within it that may cnable it to be made into an iron ship incorrodible in water, although without any external protection whatever. Indeed, did the passirity of iron extend to the chlorine compounds, as it docs so far as is yet known only to the oxygen compounds, the end might be at once accomplished. By experiments carried on in Kingstown Harbour and in various other places upon the actual rate of corrosion of exposed surfaces, say a square foot of iron, for lengthened periods of three or four years, I have ascertained the rate of corrosion for iron, enst, wrought, and steel, from rarious makcrs, of different qualities, in various conditions, and in rarious waters, such as fresh and salt, and each both pure and foul by kewage, \&.c.; ninl I may state as one result of these experiments that the rate of corrosion for wrought iron in clear sea vater-I am now talking of arerage iron, such as is nsed for ordinary ship building- Trould bo such that, corroded on one surface only, six-tenths of an inch in depth would be taken array in a century. That is the rate at which an iron ship in sea water will corrode if not protected by paint or angthing else. If protected by certain varnishes or coatings, the progress of corrosion may be chomously retarded.

The Cuarmans. - Six-tenths of an inch in depth?

Mr. Mallet.-Tes; six-tenths of an inch in depth in a century. That is to say, if the plates wero sir-tenths of an inch in thickness, and acted upon on one side only, the iron rould be all gone in $n$ century. This supposes that corrosion takes place uniformly and aliko all orer the surface; but that condition does not hold as respects the surface of an iron ship; there are parts where the action is much more rapigl than at others, and round the rivet seams corrosian takes place, coteris paribus, much more rapidly than anywhere elsc, from the rircts being harder owing to the process of closing, than the rest of the plate, and lence slightly clectronegative to the plates of the ship, or in the like relation to them as a piece of colpper. It was long ngo ascertained by Professor Edmund Davy, nepher of the celebrated Sir Humphry, that iron possesses tho property of being protectel, by zine attached to it in mass, in the same way that Sir Humphry Dary showed jears before that copper sheathing could be protecterl by zinc protectors. I ascertained that the hnll of an iron ship conld be protected to a rery great extent from that unirersal corrosion which takes place, hy the attachment in mass of a surface of zinc, only 
extending to $\frac{1}{120}$ th of surface of the exposed irnn. But that will not stop such corrosion of an iron ship as goes on close to where the wash of the paddle-mheels affects ler sides, nor near the bows, and other parts where the air and water are constantly agitated and renered in contact with the iron, and fresh surfaces of the latter constantly exposed by the washing away of the rust already formed. The moment you produce protection with zinc, lowever, you get a deposit upon the surface of the iron of carbonate of lime in crystals-calcspar, in fact, in the ordinary rhombic form-produced by decomposition of the salts of lime in the sea water; and so the groundrork for fouling is at once laid, and it increases then at an enormous rate. I further ascertained that if the rnte of corrosion of iron in an iron ship-the iron plates alone being exposed to sea water, be represented by a number equal to 8-then, if exposed in contact with copper, such as copper shenthing, in the proportion of two to three, that is to say, three square fect of iron to tro square feet of copper, in that case the rate of corrosion will be increased in the ratio of 11 to 8 , the iron corroding alone at the rate of 8 , but at the increased rate of 11 if it be in contact with two-thirds of its own surface of copper. But I ascertained a further fact, which is an important one. Ordinary gun-metal, such as is used for the screws of our propellers (alloys of copper with 8, 10, or 12 per cent of tin), possesses the porrer of increasing the corrosion of irrought iron enormously more than pure copper itself, so much so that if the three square fect of iron we were talking of were in contact rith tro square fect of gun-metal, the rate of corrosion is increased, not from 8 up to 11 , but from 8 to 19 . In connection with this fact I may obserre that $I$ hare seen it stated that a great number of the iron ships now being sent to sea, or in preparation for sca, by the Almiralty, are fitted with gum-metal propellers. If such be the fact, anything more injudicions or more uselessly destructive to the iron of an iron ship cau scarcely be conceived, nor anything more unnecessary. Every marineengine maker knows perfectly well that cast-iron propellers, or wroughtiron propellers, may lo made perfectly safe, weight for meight, with those of gun-metal. It is hard to see, therefore, why this'material, that costs about $2 s$. a pound, should continue to be used, where a material which costs about 3 lad. or $4 d$. a pound ought to be used instead; the dearer material being positively mischievous to the iron ship as well as to the scrembearings, \&c. I also ascertained that among the conccirable alloys of copper and zinc with which an iron ship might be corered, was one closely approaching to the alloy linown as Miuntz's metal, but not identical with it. This was an alloy of four atoms of copper to one of zine, very nearly the composition formerly knom as Dutch brass. It is a remarkable fact that the galvanic action on iron in sea water of this particular alloy is almost nil. A ressel coated with such an alloy, the surfaces being in the proportion of 3 to 2 as before, the rate of corrosion of the iron is only accelerated in the proportion of $9 \frac{1}{2}$ to 8 ; the iron is hence rery little worse than if not in contact with any electro-negative metal at all. So far as the chemical properties of this alloy are concerned, it might be applied directly; therefore, to sheathing an iron ship; but any attenpt at coating an iron ship directly with any metal sheathing is quite ont of the question. The mechanical difficulties are insuperable; you caunot attach slicatling firmly 
to the skin of an iron slip in any way, but you injure the strength and diminish the safety of the ship enormously. There is another class of facts to which I may briefly refer. The rate of corrosion of iron in sea water greatly depends, other things being the same, upon the quality of the iron; I do not mean the quality of the iron in the sense in which we usually apply the word in the market, namely, the rery best iron as regards toughness and strength. Here is a fact, ascertained by sereral years' exposure of large surfaces, and therefore reliable,-that an equal surface of the hull of a ship built of the common plates known in commerce as "boat plates "-the worst class, in fact, of Staffordshire or Yorkshire plates-will corrode in a giren time at the rato of 36 , while an equal surface if made of the very best plates of cold-blast South Wales iron will corrode only at the rate of about $8 \frac{1}{2}$ to 9 ; and that if the plates are of very highly-wrought iron worked orer and orer again, such as faggoted scraped iron when rolled into plates, or Low Moor or Borling iron, then the rate of corrosion will be only $2 \frac{1}{2}$ in the same time for equal surfaces. It is hence apparent how much is lost in durability and in freedom from corrosion and fouling as rell as in strength, by the too prevalent use of inferior qualities of iron for shipbuilding. I will now drop the question of corrosion and come to that of fouling. The two, howerer, are inseparably connected, and for this reason, that if it were possible to get the hull of an iron ship into a condition that it wonld nat corrode at all, there would no longer be any difficulty about prerenting it from fouling at all. It was Jears ago ascertained by Prinsep of the India Service-

Captnin Halsted, R.N.- Which of them?-because there were sereral brothers.

Mr. Marlex.-James; ho was attached to the Calcutta mint. $\mathrm{He}$ ascertained the fact that, if Jou oil or cont a surface of iron with any greasy varmish or with any shiny material, such as the native Sylhet varnish of India, or eren with common drying oil-so long as a restige of such a coating remains upon the surface, none of the lower forms of animal life attach themselves to it. The cause is apparently a purely mechanical one. The surface is so smooth that the animal is not able to attach himself $\rightarrow$ the smallest wash of the water washes him off. But whaterer be the cause, if we could get that sort of greasy material or any vamish to stick to iron permanently, we could prerent the fouling; but no coating has erer yet been derised that will accomplish this. Innumerable coating compositions have been proposed. I have myself a list, made for me some months ago, of about serenty patents that have been taken out, since the date of my British Association Report of 1843, of different nostrums for prerenting the fouling of iron ships. They are all failures; not one of them has answered, not even excluding my own, which was the origin and predecessor of them all. And I may mention further: there is not one of these patent compositions that is not simply ringing the changes upon what was originally proposed ly myself. In $1813 \mathrm{MIr}$. William Fairbairn and I patented a mode of preventing the fouling of iron ships. It was based on lengthened observations I had made as to what were the conditions under which animal and regetable life attach themselres to iron ships, and what were the conditions that would be 
disadrantageous to both. My researches rere conducted upon many of the lower forms of marine animal life; and I was then enabled, by liring on the seashore, to carry them out with the necessary accuracy and facility. I experimented on oysters, sea-anemones, mytilus, balanus, lepas, patella, and sereral other forms of lower marine life, besides regetable marine forms -such as fuci, conferra, byssus, \&c. I found this curious fact mith respect to these lorer molluscous animals: that the soluble poisons, prorided these creatures are very slorly accustomed to them, do not seem in any serious degree to affect them. I had some of these animals in glass jars for two or three years, with constantly renewed aëration of the sea water. At stated interrals a fer drops of some soluble poison-for example, sulphate of copper-were dropped into some of the jars. At last I had oysters living in apparent health in a solution of sulphate of copper, which, if any one of us were to drink half an inch deep out of the glass, would hare poisoned us, or produced romiting. The animals became so thoroughly impregnated with copper, that, if you thrust a common penlinife into one of them, and let it remain in his body a short time, the blade came out coated with copper. The oysters themselves did not seem particularly annoyed for lengthened periods, prorided the process was conducted cxeecdingly gradually; they all, howerer, contracted in bulk, and died when the poison reached a certain amount of concentration. If you were to put an ordinary oyster, not accustomed to these bad habits of poisonous dram-drinking, suddenly into the same coppery water, it would die within a very few hours. The facts are analogons with the well-known powers of passire endurance of all the lower forms of life. The same, however, does not hold with poisons of an insoluble, or, rather, difficultly soluble, character, put in a solid but finely-divided state in contact with such animals. An oyster or sea-anemone put into a jar of sea water, into which were dropped a very few grains in fine pouder of-say, realgar or sulphuret of arsenic, and stirred up, is sure to be deprived of life; it could not exist under such circumstances many hours. The solid grains of the insoluble poison appear to be bronght into the fine cells of the branchix--such as the beard of the oyster-and he has not the porrer of eliminating them, and the animal is poisoned, by the irritating contact probally. Whether that is the explanation, I am not naturalist enough to lnow; but I can rouch for the facts. My method, which Fairbaim and I patented, was based upon these. It consisted in coating the iron plates, after they had been thoroughly well liented by lighting coke fires under the bottom of the ship in dock, with boiled conl-tar chiefly, and on that was laid a slowly soluble rarnish, a sort of metallic soap, containing difficultly-soluble poisonous matter. It was mainly formed of common bright rarnish, coalpitch, soft soap, and the poisonous matters, several of which were proposed; but the one which I adrised as best was " realgar," or sulphuret of arsenic. I went to Liverpool to see the iron-ship builders, and, amongst others, the late Mr. Laird, with the riew to get them to adopt my method. At that time the slip-builders, one and all, said, "Oh, iron ships do not foul at all, and as to corrosion they will last for ever; but in any case" (one of them told me) "we do not want your method, we have some of our own that will do as well." A few months afterwards I found that a ressel had actually been coated at Liverpool. I sacceeded in obtaining some of the 
coating, and I found that it consisted of bright ramish, tallow, flowers of sulphur, and white arsenic-that is to sas, it was precisely the four ingredients of which my patent consisted, only combined in another shape. All similar compositions that are now used, and which hare the best reputation, consist of partially insoluble salts, cither of copper or arsenic, or of both, mixed generally with a lot of nostrums which are of no use rhaterer. Thes are at best mere palliatires, for it is a fact that they all do foul, after a time longer or shorter, orer the whole surface. The stuff gets stripped of by the wnshing of the rater, or accidentally, and as soon as that takes place the remaining portion begins to get coated with a thin film of carbonate of lime, deposited from the lime in the sea mater; and the moment that deposit takes place the surface becomes a fit nidus for the lower marine animals and regetnbles, and then fonling goes on. We thercfore come to this conclusion, that some better method is wanted for the protection of iron ships than is afforded by any chemico-mechanical method of coating jet proposed. Now, I would make one or two remarks of a purely practical character upon what $\mathrm{Mr}$. Grantham has brought before us. To prevent any misapprehension, I wish to state that I have no personal interest in Mr. Grantham or his patent, direct or indirect; I stand hero by inritation of this body, to which I hare the honour to belong, simply to state, for the information of those around me and for the good of our conmon fatherland, whatever knowledge I have acquired applicable to the subject. Mr. Grantham's method amounts to this : we must all aclmit that if we could put an iron ship into a water-tight rooden saucer of her own form, and let her go to sen in that rooden casing, corrosion or fouling conld not take place on her bottom; whatever happened must happen to the wood. The question therefore is, can Jou make a watertight rooden saucer round an iron ship? Mr. Grantham proposes to do so, and, for anything I sec to the contrary, I think he can succeed. His method is this: he spaces over the skin of the slip a number of doretailed ribs of iron rireted to the slin, and betreen these ho drires in, and caullis water-tight pieces of wood; the dovetails hold them on withont piercing the skin anywhere, and the caulling makes the rood slin water-tight; orer all this ho places what other metallic sheathing seems good to him. I conceire there can be no possiblo doubt that picces of mood may be driven into doretailed recesses of that sort, with no moro skill than that of ordinary shipwright mork, so ns to male them prnctically waler-tight. When such a mooden surface is coated orer with another of planking, properly eccured rith felt or tarred paper between, and also caulked, I can scarcely conceive the possibility, while the hull remains sound, of water finding its ray inside. But if the sea mater should find its way in, the amount of corrosion that could take place, unless there were a stream of water in and out so as constantly to renew the agents of corrosion, would be next to nothing. I lave already shown you that if a piece of iron be put into water already robbed of combined air, or if you exclude the air from it, it will not corrode at all. Therefore, if water should get in and Indge behind any one of these blocks of rood, unless it bo perpetually renerred by $a$ stream in and a stream out, the water that has got in there will, after a short time, lave next to no power in the way of corrosion. I understand from Mr. Grantham that the onter planking will be secured by brass ecrewe. 
Mr. Graxtmasr-And the senms rould be caulked as well.

Mr. Maldet,-So I hearl; but it appears to me that if these inner blocks were fitted and driren in dry with a reasonable degree of accurate workmanship, they would become water-tight without auy caulking wlinterer. This first coat unay be sheeted rith bromn paper or felt under the planking, and then the planking applied and that caulked. Irould then ask, is there any objection to putting on the outer planking with rood trenails in place of with brass screws, as here shom, for in that case there rould be absolutely no inetallic contact of any sort betreen the copper or other sheathing and the skin of the ship.

Mr. Grinthay. - There mould be no metallic contact.

Mr. MLablex.-In that case I take it that the copper mould prodice no cffect on the ship. The copper would itself be exposed to the nction of the sea, and would be in the condition of the copper of an ordinary rooden ship. Let us now suppose that the ship grounds, or rides over her orn anchor, and tears a large picce of the rood coatings off her bottom. It would hare to be a very heary grind, indecd, to strip off the inner blocks, because erery block supports erery other, and, therefore, you mould have to break off many of the rib irons in order to dislodge any of the blocks. But suppose sereral of them were broken off, and exposure made domn to the skin of the ship, I make no donbt but that then the exposed portion of the slin of the ship monld corrode much more rapidly than if there were na copper present hecause there rould then be metallic contact between the copper and the exposed portion of the ressel, inade good by the sea water. But then comes the question, how much greater that wonld be. I have mentioned the fact that iron and copper, being in the ratio of 2 to 3 , the increased rate of corrosion is in the ratio of 11 to 8 . Now, something more than that would be the increased rate at which corrosion would take place in the case supposed. I rould merely say this much further, that there wonld certainly be no such amount of corrosion as to endanger the safety of the ship at sea before she could get home, or into some port where the accident could be repaired. I may mention, in explanation to such chemists as may be present, that in sea water, after exposure for considerable periods of time, tho rate of corrosion of iron in presence of copjer, or other electro-negative metals, does not follow the lar of voltaic equiralents. It may appear strange that copper and iron jut togetleer into sea water should corrode in the ratio of 11 to 8, and not in the ratio of the roltaic equiralents. The fact is, lowerer, that the surfaces of both metals when left to themselres in sea water set conted more or less with various insoluble sulphates, and other salts and oxides, derived both from the iron and from the sea irater, which alter altogether the rate of corrosion that would otherwise take place mere chemical action quite unimpeded. One or tro other thoughts of a practical character occur to me. It would appear, with respect to these inner blocks, that there are some roods of which they ought to be, and some of which they nught not. I am quite clear that they onght not to loe of pine rood. Pine rood is capable of getting rapidly into a condition of softening and incipent decay on its surface; in that state it rapidly decomposes the sulphates present in sea rater, reducing them to sulphurets, which are again decomposed by the iron, and powerfully increase comosion. Stch rers soft roods, nuless 
resinous or thoroughly impregnated with creosote, ought not to be adopted. Oak I object to, because, as erery one knows, it rapidly acts on iron in contact with it, getting black and hard. It appears to me that a tough timber, elastic, and tolerably hard, would be the right thing. In fact, I doubt if anything better may be found than refuse teak out of the yards, or perhaps Honduras malogany. For the outside sheathing it does not matter what timber is used, because it only tonches the edges of the dovetail ribs. If this sheathing were made of fir these edges might be exposed to a very limited extent to the objectionable action of the incipient decay of pine timber. Therefore, I think it would be found adrisable to put a little more iron into this part (pointing to the doretail heads of the ribs) and so allow for that. Then, the question comes, what effect would be produced upon the inuer blocks by the working of the ship. Having giren that point some consideration, I doult that there would be any objectionable effect produced. An iron ship rorks in more ways than one. $\Lambda \mathrm{t}$ sea erery ship rertically works up and dorn; it also twists. In rooden ships nothing could be more remarkable than the extent of the latter morement. I recollect reading of some old ship of Collingwood's, the stern of which, when she rolled, tumbled orer 8 or 9 inches on cach side from the looseness of the framing. That is the sort of motion which rould be most likely to dislodge these blocks-not by any single motion, because, if you suppose the "Warrior" twisting eren 8 or 9 inches, the effect of any one such morement on any block would be perfectly imperceptible, but, if that sort of working were continuous, it would bo difficult to say how far it might result in gradually loosening the timber at last. This is a conceivalle possibility, but $I$ do not adduce it as a real or tangible objection. Our ships ought not to work or strain, and my own impression is that not any of these blocks would work loose. I think I hare nearly exhausted the observations which it has been desirable to make, unless something should ariso in the discussion, when $I$ rould ask permission to make further observations. In conclusion, I would say that Mr. Grantham's invention scems to me well deserving of a trial upon a large scale and in an effectual manner. Such a trial can, in fact, only be instituted by a Government department-such as the Admiralty.

The Curmuax.-- IVill you allow me to offer your thanks to Mr. Mallet before me procced. He is not an ordinary speaker on the subject. $\mathrm{He}$ has illustrated and cxplained it in a manner which only a man can do who is master of the subject; and $I$ think he is entitled to our thanks for the information he has giren us. We will now pass on to the discussion.

Captain HALsted, R.N.-Last year I expressed my own conviction, which has never been altered since, that this is a mechanical arrangement which seems to be the most practically arailable that $I$ have seen. All I would say upon it is this: I would advise Mr. Grantham not to gire up one single hair's-breadth in the way of the reduction of the iron plate in order to accommodate the exterior lining, because I believe the adrantage of such protection as would be given is a thousand times more than compensated by the advantages to be gained by loss of weight, that is to say, if it increased weight upon the structure of a ship would be 280 tons, by all means make the ship 280 tons Jarger to carry it. Nothing can exceed the misery of the circumstances in which we are now placed. We ought never to have arrived at it. There has never been a national effort made, nor anj combined effort, to prerent an injury 
which is absolutely destroying the application of the most effective material for the ships of the Navy. I regard it as a great disgrace to the whole country that such a state of things should exist, and I am perfectly persuaded that by this time we ought to have ascertained that the thing is remediable by chemical application, or to have ascertained under what conditions it can be placed to effect a reduction of the fouling. If that is impossible, then we have got other resources to fall back upon, that is to say, you can make a substitution of metal. Mr. Mallet has mentioned Muntz's metal. Muntz's metal has been shown to be perfectly equal in strength to iron, and the qucstion is of that importance that I do not think the matter of expense ought to enter into the consideration. I do not think any expense can equal that of being obliged to forego the actual usc of iron ships, for if a ship has to leave her station in order to be cleansed, she is unservicenble on her station for the time, and nobody knows whatmight happen when she is absent; therefore I do not think the question of expense ought to be entertained at all. Mr. Grantham here proposes a mechanical mode of rectifying our present position, and I have no hesitation in saying that, so far as an unproved thing can be judged of, because we bave no experience in it, $I$ think it is eminently deserving of application; and as we hare at the present time a new kind of ship which is about to be commenced, and which is to be made the subject of experiments, I would advise Mr. Grantham to press very hard to have his application applied to the bottom of Captain Coles's cupola ship. I am strongly of opinion that Captain Coles would not make the slightest objection; on the contrary, if the method has the effect of maintaining the efficiency of his ship infinitely longer than otherwise she could be with a bare iron bottom, I believe Captain Coles would jump at it. Moreover there seems to be a desire on the part of the Admiralty to make that ship an experimental ship for more purposes than one. I see they are going to apply one or two different modes of fixing the armour-plates, and I should advise Mr. Grantham to make a set at that point. There is also this suggestion which I would make to him, which is, the use of Muntz's metal and not of copper. It is a mere routine we have got into with regard to the use of copper. The whole mercantile service of the country use Muntz's metal instead of copper. It is infinitely better, it is absolutely cheaper; the restoration or: re-construction of it when it is worn is quite as easy as that of copper. Our cstahlishment down at Chatham, where we make all the copper for our ships, is just as available for making Muntz's metal as it is for making copper. I had Muntz's metal in use on a ship which I commanded. At the time when screws were first introduced, before we adopted our present mode of lifting the screw, we used to withdraw it; the ends of the shafts nere then left cxposed, and the galvanic action was very powerful indeed. The series of experiments to which Mr. Mallet has referred were then made, for the purpose of ascertaining whether any other mixture would exhibit less powerful galvanic action than that which was done by the copper, and all the aft-part of our screw-ships, up to the year 1853, were sheathed with Muntz's metal. The ship I commanded was sheathed entirely with Muntz's metal. I preferred it, and the bottom of my ship was cleaner than those of the other frigates with which I was lying.

Dr. Percy, F.R.S.-I have listened with great attention to Mr. Mallet, and have been struck with many remarks, and with none more so than those which related to the purity of certain qualities of iron. I think $\mathrm{Mr}$. Mallet stated that certain descriptions of iron which were known to be most pure, resisted corrosion most effectircly. If that be a fact, it is one of very great importance, because $I$ believe that this particular kind of iron would be found to possess the very highest degree of tenacity, and to be, therefore, the best possible iron for use in structures of this kind. It appears to me that the subject is very far from being exhausted. Although many experiments have been made on the application of various kinds of cements, and although many patents have been taken out, and, as is customary, the same thing has been patented over and over again; still I cannot help thinking that an experiment of a very important character yet deserves to be made. I should like to hare heard what Mr. Mallet's experience was as to the application of metallic coating. I think he condemned them all without any reservation. I do not know myself whether many experiments have been made. If they hare not, it certainly seems desirable that something of the kind should be done-such as the application of arsenic. It is quite possible to apply arsenic in more ways than one to a surface of iron, and not only arsenic, but other metalic bodies. It may turn out that these applications are useless; but until we have the experiments, we are not in a position to speak with any degree of authority on the point. With refer. 
ence to the remark which Captain Halsted made upon the substitution of Muntz's metal, I think that is a subject of very great importance. It is a subject about which I have recently placed my own views on public record; therefore I will not detain you with any remarks thereon.

The Cratrian.-Perhaps you concur in Ceptain Halsted's views?

Dr. Pracy. - I am not prepared to say that. I think it is a subject worthy of more attention than it has yet received. Probably the Admiralty hare some good reason for preferring copper. I believe in the case of Muntz's metal it is necessary that the ressel should be examined and repaired after a comparatively short time.

Captain HALSTED.-No, that is not so. It is almost unirersally adopted in the merchant service, and $I$ hare had it in my own ship.

Dr. PercY.- How long witlout cleaning? That is the point.

Captain HALSTED.-We were more than two years before we were taken into dock.

Dr. PEREY. - Is not that a short time for ressels of war?

Captain HALsted.- She was not taken in purposely for it; she came into doek accidentally, and, when she did come in, arrangements were made for an examination of the amount of fouling as compared with copper. The result of that examination is with the Admiralty.

Dr. PERCY. - The explanation of that is, that the zinc is perpetually dissolving away, so that the hold of these animals is prevented. In the course of time the whole of the zinc disappears; so you see, here corrosion plass a very important part.

Captain HAsSTED.-It may depend upon the amount of metal; but in the case of my own ship I know that the report now exists, and I know how very little we had to do, because we had a clean bottom when the ship was taken into dock.

Dr. Percy.-That leads me to another question about the effect of corrosion in the way of prerenting the attachment of these shells, ace. One would think, à priori, that in proportion to the degree of corrosion would be the difficulty of attachment. I do not know whether I am right in my view. A certain amount of corrosion, I believe, would be desirable in caies of this kind, unless jou have that degree of absolute smoothness to which Mr. Mallet has called attention.

Geo. Turner, Esq., Master Shipwright, Woolwich Dockyard,-I do not think the copper sheathing is altogether free from fouling. I recollect a case in which we took off about ten tons of mussels from the bottom of a ship.

The Chatrman.-It is a question of degree.

Mr. Tunker.-I have known copper on the old "Royal Sovereign" (it was pure copper then; we have lost the making of it) that had been on twenty-one sears, and there was no diminution at all. How to account for it it was impossible to say, but such was the fact.

Cuaries Arherton, Esq., Chief Engineer and Inspector of Machinery, Woolwich Dockyard. - I will not attempt to detain the Meeting, but I would remind Captain Halsted of an experiment which was made at Woolwich fifteen years aro, when an iron boat was corered with an adhesire kind of kamptulicon about an inch thick, and on this a complete surface of copper was laid by adhesion, and it was very difficult to take it off. The experiment was not completed, but it shows that something of the same kind might be made applicable to sheathing the bottoms of ships. I believe that it is admitted that bitumen is the best material for adhering to iron. With regand to those experiments which Mr. Mallet has brought forward to-night, I would not think of turning such things into ridicule, but the experiments are so wonderful that it almost makes one suppose that a clcrer fellow can produce any results he pleases. There is one curious thing about the connection of brass and iron. I have been in the habit of breaking up boilers that have been tubed in brass-brass tubes in iron plates; I do not remember to have seen any of the plates the worse for the brass tubes fitted in them.

Mr. MalLET.-Assuming the fact, a scientific explanation of it is not difficult nor inconsistent with anything $I$ have stated. The iron pans in which salt is prepared in the Cheshire Salt Works, craporate boiling brine, and yet are acted upon scarcely at all. Water holding a saturated solution of salt contains no air, and this is exactly in accordance with what I explained at the outset, that iron placed in water from which combincd air has been exhausted, will not corrode. That is more or less the case in every marine boiler. But the more efficient cause which protects the brass tubes, and every part of the interior of a marine boiler is, that before the boiler has been in action sir hours a stony deposit (insoluble salts of lime chiefly) takes place 
un the surface, and this protects it from further corrosive action; there is no unetallic surface exposed, there being a thin flm of deposit between the ratcr and the sides of the boller. With reference to some remarks of Dr. Percy, I would mention first, with respect to Muntz's metal-and this was one of the things I had intended to allude to before-I see no reason why Muntz's inetal should not be substituted for copper in Mr. Grantham's case. Muntz's metal was not the peculiar alloy of no action that I was talking of, which leaves the iron in its nearly neutral condition, but I think Muntz's metal would be an adrantagcous substitute for copper in this instance, and would produce less effect on the iron in any case than copper would. I rould not recommend the fastenings here or anywhere else to be of Muntz's metal, for there can be no more deceptive or unsafe metal for bolts or other fastenings than it is. In the course of time it gets into a crystallized condition, and a bolt that will bear nineteen tons to the square inch when first rolled, may in the course of a few months, or eren a few dass, break as casily almost as a piece of crockery. Dr. Percy has asked mea question with reference to metallic coating. In speaking of metellic coating, I alluded only to galvanizingcoating with zinc, or with zine and tin.

These hare been tried, and found ineffective in sca water, for reasons which I lave before alluded to; but I entirely agree with Dr. Percy, that the subject of modifyin: the substance or surface of the iron is not exhausted; that a great dcal might yet be done in the way of carefully and realls scientifically-conducted research, with such means given to assist experiment as the public departments can alone supply, and not by the voluntary labour and research of private individuals, as was my case. My experiments were made purely for the sale of knowledge, and at the expense of the British Assoclation, which spent $£ 300$ or $£ 400$ upon these expcriments; but such experiments, to be conducted right, would nced larger amounts, and the appliances which the public dockyards could afford to be placed in the hands of scientific men. Another dircction of inquiry is open, which Dr. Percy, talking of this and analogous subjects a few days ago, stated to me. He, I believe, holds the view that a large field of inquiry exists as to how far certain minute alloys of other metais mixed with iron for ship plates might be attended with an available diminution of corrosion and also of fouling. It is a fact, as I have mentioned, that the purest iron corrodes by much the slorrest, and that such iron therefore makes the best as well as the strongest ships. The quality of iron that is commonly used for iron ships, called boat-plate iron, is not only the worst mechanically, but the worst chemically. But it remains still for the chemist, the metallurgist, and the engineer together, to discover whether it may not be possible to make some compound of iron of this best quality, with another metal in small proportion, that as respects the ends in view shall be best of all.

The Cinsirsian.-It is really a very important subject, and we were turning over in our minds whether we could not find a day to carry on the discussion. We are very much indebted to Mr. Mallet and Dr. Percy for the rery pertinent facts they hare brought forward to-night. When we were discussing the subject of iron ships, a number of facts, which then appeared to be opposing facts, are now explained by the different qualities of the iron, and the different degrees of susceptibility to corrode. If an inferior iron is used, a ship of that description is worth next to nothing; and a ship of the very best description of iron is worth a great deal, and would perhaps be the best description of ship, if only the effect of fouling was disposed of. Since the remark with respect to the loss of a knot per hour in the speed of the Irish boats, 1 have made a calculation as to the cost. It would be equal to about one-sixth of the whole quantity of coals they burn ; and, taking the reduction of speed from fouling the bottom of the "Warrior," as estimated by Mr. Grantham-not at the figures he puts it, seven to twelve-but taking a reduction of speet equal to one-third, it would make a difference of about 50 tons of coal a-day in that ship. Abroad coals are not to be obtained under $\ell_{2}$ per ton, sometimes at not less than $£ 4$ per ton; but take it at $£ 2$ per ton, and there is $£ 100$ per day lost by the diminished speed of the vessel through fouling. Now Mr. Grantham's estimate for his sheathing is only $£ 4,000$; we see from the above how soon that would be realised in the saving of coal. But, as Captain Halsted justly observed, that is no measure of the ship's performance, because if she has to go 1,000 miles to be docked the whole use of the ship is lost during the period she is away. If sbe is the type of a fleet, and all the ressels are liable to become thus defective, the whole flect may require to go away or become weakened, so that the mischief they were intended to prevent may be effected in its absence. It strikes me that this method of Mr. Grantham's is really a complete one. I do not 


\section{ON THE PROTECTION OF THE BOTTONS OF IRON SHIPS,}

think it is of that character which requires to be what they call "tested." I am perfectly satisfied with the explanation which Mr. Mallet has given, that there is no danger, no material danger, if only the right description of wood is used, and ordinary care is taken in putting the sheathing on,-I agree with him that no water, in any great quantity materially to injure the construction, can get in; therefore it is really perfect of its kind. It would be paid for in a short time, and the efficiency of the vessel would be preserved. Twenty-fire years ago I was on the const of Africa when an iron whaler came out. She had only been six months out from England. She had been cleaned, as well as they could clean a vessel at sea, every month, with long brooms and ropes, under her bottom; but she had long grass and barnacles of immense size attached to her, in consequence of which she was not safe. She would neither sail nor steer, added to which she was not manageable. Her crew had this enormous work entailed upon them besides their ordinary work. I made a report to the Admiralty on the subject, and, with such before them, it was not to be wondered at that they did not undertake to embark in iron ships: they may be very effective, the iron may be very good, but if they foul in this way they will be useless. It appears to me that this system does get rid of that difficulty. I do not think the seams would open in any injurious degree, for a threedecked ship of the old style only broke her sheer fifteen inches in launching. After the new system was introduced by Sir Robert Seppings, similar ships only broke three inches in coming off the stocks. When you come to divide the largest quantity over the number of these small sections or plates, you will see that it can have no appreciable effect on the joints; and when you consider that the seams of wooden ships are so open that in caulking them you sometimes drive in oakum equal to inch rope, the thickness of the twentieth part of a sheet of paper is really no opening whatever. "With the best ship, when first launched, the scams are of immense size as compared with the opening which is supposed possible to arise from the bending of the ship.

We have to return our best thanks to Mr. Grantham for his interesting paper. 